\title{
Inclusive development strategy in an era of globalization
}

\author{
Working Paper No. 35
}

Ignacy Sachs

Policy Integration Department

World Commission on the Social Dimension of Globalization

International Labour Office

Geneva

May 2004 


\section{Copyright (C) International Labour Organization 2004}

Publications of the International Labour Office enjoy copyright under Protocol 2 of the Universal Copyright Convention. Nevertheless, short excerpts from them may be reproduced without authorization, on condition that the source is indicated. For rights of reproduction or translation, application should be made to the Publications Bureau (Rights and Permissions), International Labour Office, CH-1211 Geneva 22, Switzerland. The International Labour Office welcomes such applications.

Libraries, institutions and other users registered in the United Kingdom with the Copyright Licensing Agency, 90 Tottenham Court Road, London W1T 4LP [Fax: (+44) (0)20 7631 5500; email: cla@cla.co.uk], in the United States with the Copyright Clearance Center, 222 Rosewood Drive, Danvers, MA 01923 [Fax: (+1) (978) 750 4470; email: info@,copyright.com] or in other countries with associated Reproduction Rights Organizations, may make photocopies in accordance with the licences issued to them for this purpose.

ISBN 92-2-116023-8 (printed version)

ISBN 92-2-116024-6 (web version)

First published 2004

Cover:

The designations employed in ILO publications, which are in conformity with United Nations practice, and the presentation of material therein do not imply the expression of any opinion whatsoever on the part of the International Labour Office concerning the legal status of any country, area or territory or of its authorities, or concerning the delimitation of its frontiers

The responsibility for opinions expressed in signed articles, studies and other contributions rests solely with their authors, and publication does not constitute an endorsement by the International Labour Office of the opinions expressed in them.

Reference to names of firms and commercial products and processes does not imply their endorsement by the International Labour Office, and any failure to mention a particular firm, commercial product or process is not a sign of disapproval.

ILO publications can be obtained through major booksellers or ILO local offices in many countries, or direct from ILO Publications, International Labour Office, CH-1211 Geneva 22, Switzerland. Catalogues or lists of new publications are available free of charge from the above address, or by email: pubvente@ilo.org

Visit our website: $\underline{\text { Www.ilo.org/publns }}$

Printed by the International Labour Office, Geneva, Switzerland 


\section{Inclusive development strategy in an era of globalization}

\section{Contents}

Foreword $\mathrm{i}$

Preface. i

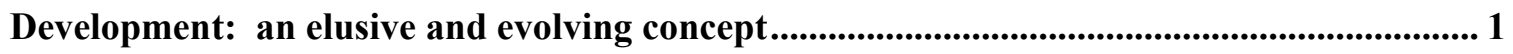

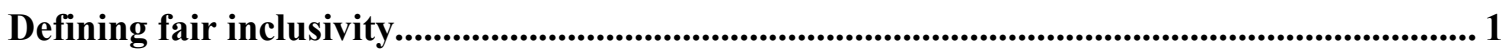

Higher productivity and more jobs: maximizing the labour content of growth................... 1

From petty producers to micro-entrepreneurs................................................................. 1

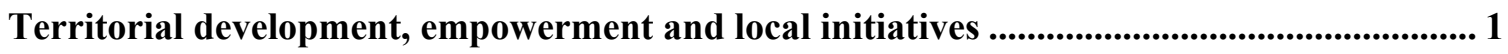

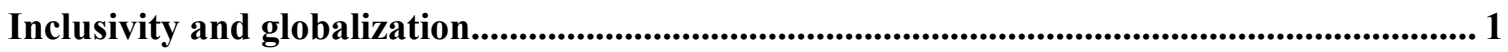

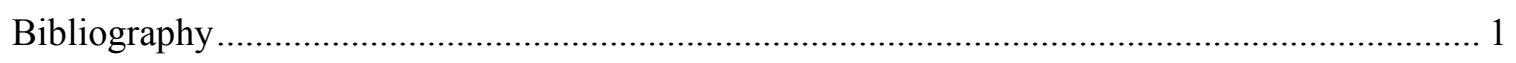





\title{
Foreword
}

In February 2002, the ILO established an independent World Commission on the Social Dimension of Globalization, co-chaired by President Tarja Halonen of Finland and President Benjamin Mkapa of Tanzania and comprising 26 eminent commissioners from a wide range of walks of life and different parts of the world, each serving in their individual capacity. Its broad goals were: to identify policies for globalization that reduce poverty, foster growth and development in open economies, and widen opportunities for decent work; to explore ways to make globalization inclusive, so that the process can be seen to be fair for all, both between and within countries; to promote a more focused international dialogue on the social dimension of globalization; to build consensus among key actors and stakeholders on appropriate policy responses; and to assist the international community forge greater policy coherence in order to advance both economic and social goals in the global economy.

The report of the World Commission, A fair globalization: Creating opportunities for all, was released on 24 February 2004. It is available on the Commission's website www.ilo.org/public/english/wcsdg/index.htm.

A secretariat was established by the ILO to support the Commission. Among other tasks, it compiled information and commissioned papers on different aspects of the social dimension of globalization. The aim was to provide the Commission with documentation and data on a wide range of options and opinions concerning subjects within its mandate, without committing the Commission or individual Commissioners to any particular position on the issues or policies concerned.

Material from this background work is being made available as working papers, as national and regional reports on meetings and dialogues, and in other forms. Responsibility for the content of these papers and publications rests fully with their authors and their publication does not constitute an endorsement by the World Commission or the ILO of the opinions expressed in them.

\author{
Gerry Rodgers \\ Director \\ Policy Integration Department
}





\section{Preface}

The Technical Secretariat to support the World Commission on the Social Dimension of Globalization first prepared a synthesis of ILO activities on the Social Dimension of Globalization (published as Working Paper No. 1 in this series). Documentation on the work and outcomes of other major commissions, an ideas bank, a database and knowledge networks of experts and social actors were subsequently developed. These networks have dealt with several topics, including: inclusion at the national level for the benefits of globalization to reach more people; local markets and policies; cross-border networks of production to promote decent work, growth and development; international migration as part of the Global Policy Agenda; international governance (including trade and finance); the relationship between culture and globalization; and values and goals in globalization. Gender and employment aspects were addressed throughout this work. The Reports on the Secretariat's Knowledge Network Meetings are available on the Commission's web site or as a special publication from the ILO (ISBN92-2-115711-1).

During the course of these activities, a number of substantive background papers were prepared, which are now made available for wider circulation in the Policy Integration Department's Working Paper series (Nos. 16 to 38), as well as on the Commission's website.

Professor Ignacy Sachs, Directeur d'Etudes Honoraire, École des Hautes Études en Sciences Sociales in Paris, assumes in this paper that sovereign nation States are and will continue to be the main locus for promoting inclusive development. He argues, however, that the asymmetric and inequitable forms of globalization prevailing today are detrimental to the interests of developing countries, profiting some insiders and leaving behind many outsiders .The nation States in developing countries strive to act as a shield protecting their people from the further deterioration of their predicament. In its present forms, globalization reproduces between central and peripheral nations the same perverse concentrating and excluding pattern of growth observed within nations. As a matter of symmetry, through inclusive development it is possible to postulate the coming into being of inclusive globalization through the institution of an international economic order based on the principle of the unequal treatment of unequals, the promotion of fair trade, the increased flow of public aid without strings attached and the transformation of science and technology into public goods (in sharp contrast with TRIPS).

Professor Sachs observes that inclusive globalization would greatly facilitate the transition towards inclusive development. But he fears that, in the foreseeable future, the chances of advancing in this direction are rather slim. This serves to underline the crucial importance of national strategies based on the concept of "development from within" which should not be mistaken as a call for inward-looking strategies.

Rolph van der Hoeven

Manager, Technical Secretariat

World Commission on the Social Dimension of Globalization

May 2004 


\section{Inclusive development strategy in an era of globalization}

For 60 years, development has been a powerful idée-force, central to the work of the United Nations system, both as an analytical concept and an ideology. Like Joan Robinson's elephant, difficult to define but easy to recognize, development does not yield to being encapsulated in simple formulas. Its multidimensionality and complexity explains its elusiveness. As would be expected, the concept has been evolving throughout these years, incorporating positive and negative experiences, reflecting changing political configurations and intellectual fashions.

Discussions on development have been instrumental in refining the concept, in sharp contrast with the dismal record of actual development in many parts of the world. Hence the need to revisit the idea of development with a view to making it more operational, while reaffirming ever more firmly its centrality, particularly since the idea of development is being contested from two quarters.

The so called post-modernists propose to renounce to it on the grounds that it has acted as an ideological trap perpetuating the asymmetrical relations between dominating minorities and dominated majorities, both within and between countries. They propose to move to a post-development stage, without clearly explaining its concrete operational content. They are of course right in challenging the possibility of indefinite growth of material products given the finiteness of our planet. But this obvious truth does not say much about what we ought to be doing over the next decades to overcome the two major problems inherited from the $20^{\text {th }}$ century, despite its record of unprecedented scientific and technical progress, namely mass unemployment and growing inequality.

As for the market fundamentalists, they implicitly consider development as a redundant concept. In their view, development will occur as a natural result of economic growth thanks to the trickle down effect. There is no need for development theory. It is enough to apply modern economics, an ahistorical and universally valid discipline.

The trickle-down theory would be totally unacceptable on ethical grounds, even if it actually worked, which is not the case. In a world of appalling inequalities, it is preposterous to pretend that the rich must become even richer in order to allow the destitute to become somewhat less destitute.

To tackle these two problems, a re-approximation between ethics, economics and politics is urgently needed (Sen, 1987). As Gandhi wrote, "The economics that disregard moral and sentimental considerations are like waxworks that, being lifelike, still lack the life of the living flesh" (Gandhi, Young India, 27 October 1921). 
In so far as moral inequalities result from the social fabric, ${ }^{1}$ they can only be overcome through responsible voluntarism: public policies promoting necessary institutional transformation and organizing affirmative actions in favour of the weaker and voiceless segments of the nation, the toiling majority deprived from opportunities for decent work and livelihood and condemned to waste their lives in the daily struggle for survival.

As observed by Ricupero (2002: 64), economies do not develop just because they exist. Economic development has been a historical exception and not a general rule. It does not spontaneously result from the free interplay of market forces. Markets are but one among several institutions participating in the development process. As they are by nature myopic, socially insensitive and, according to G. Soros (2002), amoral and their regulation, or should we say re-regulation, is urgently needed in view of the dismal balance of the application of the neo-liberal prescriptions summarized in the Washington Consensus.

In a sense, the Washington Consensus acted as a counter-reform directed against the reformed capitalism which came of age in the aftermath of World War II, inspired by the writings of Keynes and Beveridge and the experiences of the American New Deal. A reformed capitalism had been developed, based around the concepts of full employment, the welfare state and planning, with a view to exorcizing the terrible memories of the Great Depression. It also provided an alternative to the "real socialism" of the Soviet bloc, which at that time appeared credible to important segments of public opinion on account of its success in mobilizing all the available labour for rapid and extensive economic growth and industrialization. $^{2}$

The 30 golden years of capitalism (1945-1975) ${ }^{3}$ coincided with the Cold War between the two world blocs and the arms race. This situation frustrated the efforts of the United Nations to build a more equitable international economic order, but at the same time created favourable conditions for developing countries to engage in policies of nonalignment and to take advantage of the best experiences of the two competing blocs. ${ }^{4}$

The situation changed radically in the course of the 1970s. The invasion of Czechoslovakia in 1968 dispelled the last illusions about the ability of the Soviet bloc to build a version of "socialism with a human face". The capitalists therefore lost some of their fears and became more arrogant. The energy crisis and its aftermath were used to discredit Keynesianism, and soon after that the neo-liberal counter-reform gained force with the election of Margaret Thatcher and Ronald Reagan.

${ }^{1}$ For a distinction between natural inequalities, see Jean-Jacques Rousseau: "Je conçois dans l'espèce humaine deux sortes d'inégalité, l'une, que j'appelle naturelle ou physique, (...) et qui consiste dans la différence d'âges, de la santé, des forces du corps et des qualités de l'esprit, ou de l'âme, l'autre, qu'on peut appeler inégalité morale ou politique, parce qu'elle dépend d'une sorte de convention, et qu'elle est établie, ou du moins autorisée, par le consentement des hommes. Celle-ci consiste dans les différents privilèges, dont quelques-uns jouissent, au préjudice des autres; comme d'être plus riches, plus honorés, plus puissants qu'eux, ou même de s'en faire obéir" (1755: 77).

${ }^{2}$ As Jean Ziegler (2002: 33) put it, the Western social democratic parties and their trade unions transformed the capitalists' fear of communist expansion into social advantages for their clients.

${ }^{3}$ Les trente glorieuses, in the terms of Jean Fourastier.

${ }^{4}$ That was certainly the case of India in Nehru's time, which was the single most important attempt at defining a real third way. 
The fall of the Berlin Wall marked the demise of real socialism as a development paradigm and left the stage wide open for the neo-liberal gospel, which dominated the scene until the late 1990s. Yet the neo-liberal paradigm did not stand up to its promises. The Argentine development tragedy ${ }^{5}$ may be considered as the demise of the Washington Consensus, if not as an ideological construct (alienating ideologies do not die easily), at least as a pragmatic programme.

It is not necessary to enter here into the polemic about the role of the International Monetary Fund (IMF) (see, in particular, Stiglitz, 2002). It may simply be noted that the only developing countries which fared reasonably well in the last decade were precisely those that refused to apply à la lettre the prescriptions enshrined in the Washington Consensus.

We are therefore sitting on the ruins of two paradigms. The moment has come to place in parentheses the neo-liberal gospel as an unhappy interlude ${ }^{6}$ and to revisit the brief history of the idea of development, which is rich in insights and recommendations that are quite pertinent for the present discussion.

\section{Development: an elusive and evolving concept}

A comprehensive history of the idea of development has yet to be written. ${ }^{7}$ The following is limited to a few observations, highlighting some points of relevance for the present discussion.

(1) It may be recalled that development thinking in its present form started in the 1940s in the context of the preparation of blueprints for post-war recovery in the devastated periphery of Europe. Hungarians, Poles and German antifascist refugees in the United Kingdom were mobilized for this task on the understanding that Eastern Europe would not fall under Soviet influence - the Yalta Conference had not yet happened.

\footnotetext{
${ }^{5}$ Marshall Bermann analysed the second part of Goethe's Faustus as the first development tragedy. By analogy we can speak of an Argentine development tragedy, a real one this time and not a litterary fiction.

${ }^{6}$ This word is used here by analogy with Gunnar Myrdal's observation that free market capitalism was but an interlude between two periods marked by State interventionism: mercantilism and then reformed capitalism.

${ }^{7}$ A first volume could deal with the forerunners, surveying early $19^{\text {th }}$ and $20^{\text {th }}$ century discussions on development avant la lettre in Russia, India, Japan, China and Latin America, as well as the contributions of authors from peripheral European countries. A second should focus on the work of post-war recovery plans for Europe developed in the United Kingdom mostly by refugees from countries under Nazi occupation, the more so as several authors subsequently joined the first generation of United Nations officials. A third volume would be required for the evaluation of the important contribution of the different United Nations and other public agencies, with special reference to the regional commissions. A fourth and last volume would concentrate on academic work, emphasizing the important contributions of thinkers from developing countries.
} 
The problems faced by these countries were quite similar to those of other peripheries: anachronistic land tenure, backward peasant agriculture, adverse terms of trade for primary commodities, incipient industrialization, chronic unemployment and underemployment and the need for an active developmental State to face the daunting challenge of establishing democratic regimes capable of simultaneously conducting post-war reconstruction and overcoming social and economic backwardness. To a large extent, the work of the first generation of development economists was inspired by the dominant economic culture of the time: primacy was given to full employment and to laying the foundations for welfare states, the need for planning ${ }^{8}$ and for State intervention in economic affairs to correct the myopia and social insensitiveness of the markets.

Half a century later, some of their original preoccupations are still topical. How to deal with structural, economic and social heterogeneity? One of the many definitions of underdevelopment insists on the impossibility of employing all the available workforce with advanced technology due to the lack of sufficient capital. Hence the need to find a compromise between, on the one hand, the goals of modernization and industrialization and, on the other, those of promoting full employment and/or selfemployment, without losing sight of the need to continuously increase productivity, the ultimate source of economic progress.

Even today, developing economies can still be described as consisting of an archipelago of modern enterprises with high labour productivity, immersed in an ocean of low or very low productivity activities, which constitute the interstitial tissue of the economic system. ${ }^{9}$ Most of the GNP comes from the archipelago. The majority of people swim in the ocean trying to survive.

Patterns of economic growth have to be evaluated within this context. Rapid growth pushed by modern enterprises will not by itself reduce the initial heterogeneity. On the contrary, it is likely to concentrate wealth and income in the hands of the happy few who are in control of the archipelago, relegating to the ocean all those who become redundant as a result of the substitution of labour by capital. Latin American authors were right in denouncing this concentrating and excluding pattern of growth (concentrador $y$ excludente), also known as immiserizing growth. Hence the need for a two-pronged strategy, in which attention is also paid to opportunities for what might be called employment-led growth, ${ }^{10}$ a subject that is dealt with in greater detail below.

(2) The political settlement reached by the Allies in Yalta put the Eastern European countries on the track of "real socialism", which was, as already noted, fairly successful over the first two post-war decades in promoting rapid and extensive growth. All available labour was put to work, ill-paid but protected against the curse of unemployment and benefiting from a fairly elaborate system of social protection. The difficulties that ultimately led to the collapse of the system were yet to emerge:

\footnotetext{
${ }^{8}$ Von Hayek's distrust of planning at that time put him in the situation of a lonely dissident.

${ }^{9}$ This description differs from the two sector models of formal and informal sector of the economy. ILO is right to say that activities may be formal or informal, but they do not represent separate sectors.

${ }^{10}$ On this point, see Sachs (1999) on Kalecki's theory of development (mondes en développement).
} 
the inability to shift from extensive growth to intensive technology-led growth and mass consumption; the impossibility of managing complex economies and societies efficiently under authoritarian regimes; and the repression manu militari of attempts at reforming the system from within. The credibility of real socialism vanished with the invasion of Prague by Soviet tanks in 1968. Gorbatchev's reforms came too late. The fall of the Berlin Wall marked the demise of the non-capitalist development paradigm known as real socialism and the victory in the Cold War of the American led capitalist coalition over the Soviet bloc.

The demise of real socialism was certainly a very important benchmark in the short history of the development idea. Some hastened to see in it the final disqualification of the concept of non-capitalist development, going as far as to proclaim the end of history. Such a conclusion seems unwarranted. As a historical and social concept, development is by nature open-ended, contrary to the notion of organic development. Other attempts at transcending capitalism may yet come, in China or elsewhere. They need not have the same fate as real socialism.

It is even more preposterous to dismiss planning as such on the basis of the failure of authoritarian, centralized and comprehensive planning of the Soviet type. The two major weaknesses of this latter type of planning were its inappropriate technical basis in the pre-computer age and, more importantly, the lack of feedback from society due to the undemocratic nature of the regime. The management of complex economies requires transparency and accountability, the circulation of accurate information and freedom of discussion, as well as pluralistic media.

By contrast with Soviet type planning, modern planning is essentially participative and based on dialogue, calling for a quadripartite negotiation process between the development stakeholders (workers, employers, public authorities and organized civil society) leading to contractual arrangements involving public authorities, enterprises, workers' organizations and organized civil society. It certainly has a bright future ahead.

(3) Most of the work on development conducted within or induced by the United Nations had as an implicit foundation the paradigm of reformed capitalism, while recognizing a basic difference between the working of developed and less developed economies: the former were essentially demand-limited, while the less developed countries shared with the socialist countries the characteristic of being mainly supply-limited and therefore dependent on investment directed at the expansion of productive capacities.

It therefore concentrated on different modalities and aspects of development in peripheral, structurally heterogeneous and predominantly capitalist market mixed economies. Each of these qualifications calls for a brief explanation:

- $\quad$ peripheral by opposition to central capitalist economies, to which they are linked by asymmetrical relations, ${ }^{11}$ as analysed by Raul Prebisch in his celebrated and still pertinent centre-periphery model (see in particular Bielschowsky, 2000; and Ricupero, 2002);

${ }^{11}$ François Perroux defined domination as an asymmetrical and irreversible relation. 
- $\quad$ structurally heterogeneous in several respects: a sharp contrast between modern urban enclaves and more or less backward rural economies; the huge social, cultural and lifestyle disparities between Westernized elites and the bulk of the population; and skewed patterns of income and wealth distribution;

- predominantly capitalist market: in so far as the capitalistic sector of the economy, while coexisting with other pre-capitalist and proto-capitalist modes of production, is the most dynamic; and

- $\quad$ mixed economies with different configurations of private and public sectors, and often an active developmental State.

Two important conceptual advances should be highlighted:

(a) Starting from the 1970 s, the attention paid to environmental issues led to a farreaching reconceptualization of development in terms of eco-development, recently renamed sustainable development.

Sustainable development is predicated on the double ethical imperative of solidarity with present and future generations, and accordingly calls for the explicitation of criteria of social sustainability, environmental sustainability and economic viability. Strictly speaking, only "win-win-win", or "three win" solutions promoting economic growth with positive social and environmental impacts therefore deserve the denomination of development.

Table 1: Patterns of economic growth

\begin{tabular}{|c|l|c|c|}
\hline & & Social impacts & Environmental impacts \\
\hline $\mathbf{1}$ & Development & + & + \\
\hline $\mathbf{2}$ & Savage & - & - \\
\hline $\mathbf{3}$ & Socially benign & + & - \\
\hline $\mathbf{4}$ & Environmentally benign & - & + \\
\hline
\end{tabular}

During the three decades that separated the 1972 United Nations Conference on the Human Environment held in Stockholm and the World Summit on Sustainable Development, which met in Johannesburg in 2002, the concept of sustainable development has been refined, leading to important epistemological advances. For the purpose of this paper it is sufficient to emphasize that social sustainability is an essential component of this concept.

With respect to the criteria of social sustainability, reference may be made to the position of Dudley Seers: economic growth, even rapid, does not bring development unless it generates employment and contributes to the reduction of poverty and inequalities. Kalecki and Seers were among the first economists in the 1960 s to point out the need to analyse economic development, not only in terms of GNP growth, but also, and perhaps primarily, in terms of employment. 
(b) The second, perhaps even more important reconceptualization, was greatly influenced by the writings of Armatya Sen (1999). Development may be redefined in terms of universalization and the effective exercise of all human rights: political, civil and civic; economic, social and cultural; as well as collective rights to development and environment. Although the rights are indivisible, the right to work should be given special status on account of its double value, intrinsic but also instrumental, in so far as decent work paves the way to the effective exercise of several other rights.

(4) The evolution of the development idea over the past half century may be summed up by pointing to the complexification represented by the addition of successive adjectives -economic, social, political, cultural, sustainable - and, more importantly, of several new problem areas. Even so, a credible paradigm is still lacking that is capable of addressing the two crucial problems already referred to: mass unemployment/ underemployment and growing inequalities.

According to the ILO, a full one-third of the workforce is unemployed or underemployed, and successive UNDP Human Development Reports document the growing gap between the incomes of affluent minorities and poor majorities. Wealth distribution is even more skewed. We live in an increasingly fragmented world, despite of all the talk of globalization. Moreover, our economies are characterized by a high degree of wastefulness. Of all the forms of wastefulness, the worst is that which destroys human lives through the absence of decent work.

Not that the victims of uneven and unequal development do not work. As Joan Robinson observed, they are much too poor to be able to afford not to work. But, at the same time, when unemployed they discover that even worse than being exploited is not being exploited. Strictly speaking, the poor majority is not therefore totally excluded from the economic sphere. The Brazilian sociologist José de Souza Martins (2002) is right when he speaks of perverse, abnormal and unequitable forms of social inclusion. ${ }^{12}$ It may, however, be said that the poor majority is practically excluded from the development process, understood as the effective appropriation of the totality of human rights (see, in particular, Kothari, 1993). Under the circumstances, fair inclusivity becomes a central requirement for development. To the extent that an adjective can draw attention to the most essential aspect of the development paradigm, we may speak of inclusive development.

\footnotetext{
${ }^{12}$ See also his interview in Folha de São Paulo, Mais!, 15 September 2002.
} 


\section{Defining fair inclusivity}

The natural approach to defining inclusive development is in opposition to the pattern of perverse growth, known in Latin American literature, as already mentioned, as "excluding" (from the consumer market) and "concentrating" (of income and wealth). Two additional features of excluding growth are:

- $\quad$ strongly segmented labour markets, which keep a large segment of the toiling majority confined to informal activities, or else condemned to eke out precarious livelihoods from small-scale family farming with hardly any access to social protection (see, for example, Rodriguez, 1998; and Revista Latinoamericana de Estudios del Trabajo, 1999); and

- the feeble participation in, or outright exclusion from political life of large sections of population who are poorly educated, underorganized and absorbed by the daily struggle for mere survival, with women, subjected to gender discrimination, being the hardest hit.

Inclusive development requires, first of all, ensuring the exercise of civil, civic and political rights. Democracy is a truly foundational value (Sen), as it also guarantees the transparency and accountability necessary for the working of development processes. However, there is a great difference between representative and direct democracy, with the latter creating better conditions for debating matters of public interest.

All citizens must have access on an equal basis to welfare programmes for the disabled, mothers and children and the elderly, which are designed to compensate for natural or physical inequalities. Compensatory social policies financed out of the redistribution of income should also include benefit for the unemployed, an almost impossible task in countries where only a tiny minority of workers are employed in the organized sector, and where open unemployment is much less significant than underemployment.

The whole population should also have equitable opportunities for access to public services, such as education, health protection and housing. A few comments are in order here.

Education is essential to development due to its intrinsic values, as it contributes to cultural awakening, awareness-raising, understanding of human rights, greater adaptability and a growing sense of autonomy, self-reliance and self-confidence. Of course, it also has an instrumental value in relation to employability. Education is a necessary, although not a sufficient condition for access to decent work. It must come in a package of development policies, even though some would like to present it as a panacea. One of the paradoxes of the prevailing situation is that the mass unemployment of adults goes hand-in-hand with intolerable child labour. In order to send all children to school, fellowships are required for those from poor families whose survival depends on the money they bring home. ${ }^{13}$

13 The pioneering programme of Bolsas escola, introduced by Cristovam Buarque in Brasilia, deserves the utmost attention in this respect. 
Important as access to health services may be, it is only part of the broader objective of improving the health condition of the people. The latter depends on adequate nutrition (food security), access to safe water, the improvement of living and working conditions, better education and preventive measures, such as vaccination.

Whether housing is a public service is open to discussion. Treating it as such in the countries of the former Soviet bloc did not bring satisfactory results. Yet provision of decent housing for all, thereby meeting a basic need, is certainly a major challenge for inclusive development. Hence the importance of popular housing policies and, in particular, schemes based on assisted self-help construction, through which the public authorities join forces with future dwellers, whose work constitutes a form of nonmonetary saving.

All four - welfare programmes, education, health and housing - require public financing through the redistribution of a portion of GNP, however they are managed: directly by the public administration, through institutions in the third sector of organized civil society, or even by private enterprises. The question of whether the first three should remain entirely in the public domain on account of their vital importance for social welfare is a matter of heated ideological discussion. Advocates of the neo-liberal paradigm instead propose market solutions, helped by the fact that the performance of the public sector in many countries has been rather poor. ${ }^{14}$

The boundaries between the public and private spheres, as well as the definition of public goods, are another matter for discussion.

More importantly, a clear distinction has to be made between compensatory policies financed by the redistribution of income through the fiscal system, and employment policies bringing about a different primary distribution of income. Both are necessary, but the former are of a purely social nature and require recurrent expenditure year after year, while the latter, by creating opportunities for decent work, generate income and provide a lasting solution to the social problem. Ceteris paribus, employment generation should be preferred to compensatory welfare policies, if only because the latter can never provide the dignity that comes with work. ${ }^{15}$

The capitalist economic system is commended for its unparalleled efficiency in producing goods (wealth), but it also excels in producing social and environmental bads. For the ideologues of market fundamentalism, these bads are the unavoidable price of economic progress. They can only be mitigated and compensated through the production of such public goods as poverty alleviation and environmental protection. In other words, mass unemployment, underemployment and social inequalities are inherent to the capitalist system, but this inconvenience is more than offset by the efficiency of the capitalist market economy.

\footnotetext{
${ }^{14}$ See, on this point, the prologue to Kannan and Pillai (2002).

15 According to Ha-Joon Chang (2002), this opinion is supported by Stiglitz, who considers that more emphasis is required on full employment and that greater participation in the labour market is an essential element of a genuinely democratic society.
} 
However, this argument rests on a very narrow definition of efficiency. In an important book on the limits of the market, Kuttner (1997) distinguishes between three kinds of efficiency: allocative efficiency, associated with the name of Adam Smith; innovative efficiency (Schumpeterian); and Keynesian efficiency, consisting of the full employment of all the means of production. I have argued elsewhere that two additional efficiencies are social efficiency (overlapping with the Keynesian concept insofar as the full employment of the workforce is concerned) and eco-efficiency. Undoubtedly, capitalism is very efficient in allocative terms, but deficient with respect to Keynesian, social and ecoefficiencies, which are essential to the concept of inclusive development, with decent work for all as its centrepiece. Far from being a parameter estimated on the basis of past performance, the employment elasticity of growth should be treated as a variable in development planning which holds the key to an inclusive development strategy. Of course, higher rates of overall economic growth are likely to bring about higher employment. But it is equally important to reflect on how to maximize employment content for a given rate of growth, without losing sight of the objective of increasing labour productivity, on which economic progress ultimately rests.

\section{Higher productivity and more jobs: maximizing the labour content of growth}

The dismal situation of the perverse growth (misdevelopment) of peripheral countries and the deteriorating employment conditions in central countries has much to do with the structural transformation of the world economy and the resulting three de-couplings identified by Peter Drucker (1986) between:

- the financial and the real economy (financiarization);

- the growth of GNP and demand for commodities, mainly as a consequence of the increased share of services in consumption patterns; and

- $\quad$ the growth of GNP and employment, due to labour-displacing technical progress.

Increased labour productivity is to be welcomed, as it constitutes the ultimate basis for economic progress. In theory, it should make it possible to advance along the path of the progressive elimination of heteronomous, painful and alienating work, thereby freeing time for autonomous economic and non-economic activities. ${ }^{16}$ Such is the essence of the generous vision proposed, among others, by Ivan Illich (1977) and André Gorz (1988).

Advanced industrial countries should no doubt reflect on the optimum use of technical progress: how much emphasis should be placed on the reduction of working time and how much on piling up additional goods? At what point should the pursuit of material growth be ceased on the grounds that the ultimate goal of development is a civilization of being and not of having, and that the finiteness of our planet sets limits on the expansion of material output?

\footnotetext{
${ }^{16}$ For the distinction between heteronomous (commanded by others) and autonomous work, see Ivan Illich (1977). The same author reminds us of the etymology of the French word "travail": the medieval torture tripallium.
} 
These are very important questions indeed for a long-term prospective debate. But they should not distract from the social urgencies that must be resolved first. While proposing the civilization of being as the goal of development, Louis-Joseph Lebret specifies as a necessary precondition an equitable sharing of having. ${ }^{17}$

Our immediate concern must obviously be the appalling inequalities existing today in access to work opportunities, pay for work, social protection and participation in the income and wealth that are generated. In the absence of equitable conditions and rules of conduct in all these realms, the objective of (heteronomous) work has no chance of becoming a realistic goal. The more so since people have yet to learn to appreciate as a true measure of their cultural freedom the time liberated for autonomous activities and to give it preference over the pleasures of consumerism.

Hic et nunc our problem therefore consists of reconciling the objectives of economic progress, fuelled by increases in labour productivity, with the imperative of providing opportunities for decent work for all. Several observations are in order in this respect:

- firstly, the reduction of work content per unit of a given product can be offset by the increase in the total demand for that product stimulated by price reductions and the overall growth of GNP brought about by technical progress;

- $\quad$ secondly, reductions in direct labour intake can go hand in hand with increased demand for labour upstream (research, design) and downstream (marketing, distribution, maintenance);

- thirdly, technical progress is instrumental in creating new products and stimulating new needs; and

- fourthly, and most importantly, losses of jobs in some sectors can be compensated by higher employment in other sectors, depending on the changes made in the global output mix and in the choice of techniques. These are the two key variables of the planning game aimed at the harmonization of the two seemingly contradictory objectives of rapid technical progress and full employment. For that a two-pronged strategy is required.

On the one hand, rapid technical progress is certainly needed in industries producing tradable goods competing on world markets. No country can afford not to have firms qualified to act as global players, even though this may imply a downsizing of their personnel.

On the other hand, the same compulsion does not apply to the production of non-tradable goods and of many other goods which belong to the category of tradables, but in practice do not face external competition on local markets, protected as they are by distance, high transportation costs or consumer preferences (for example, fresh food). Aldo Ferrer (1997 and 2002) is right to insist on the fact that nine out of every ten people are employed in production for the internal market, many of them producing non-tradable goods. The negative employment trends in modern industries should be compensated by loading the output mix as much as possible with non-tradables.

17 "une civilisation de l'être dans le partage équitable de l'avoir". 
This calls for a greater relative share of services and locally produced food (local food security) in consumption patterns, as well as greater priority on investment in infrastructure works and civil construction (especially social housing). Richard Meier (2000) went so far as to suggest that African and other developing countries should leapfrog into service societies without necessarily repeating the growth stages through which the industrialized countries passed.

The scope for employment-led growth should be fully explored by resorting to labourintensive methods in all the spheres of production of non-tradables. In other words, it is necessary to investigate the extent to which it is possible to move along these lines before meeting the barrier of the adequate supply of wage goods (a prerequisite for avoiding inflationary pressure) and/or foreign exchange shortages. As a rule, most non-tradable goods have a low import content. In many countries, local agriculture and manufacturing industries can adjust the supply of wage goods to increased demand arising out of additional employment in public works.

Moving to other sectors of the economy, the following margins of freedom should be explored:

- the potential synergies between large-scale modern enterprises and small-scale fairly labour-intensive businesses (the subcontracting of production and the tertiarization of services); a special case is the integration of small-scale rural producers into agrobusinesses (on enterprise linkages, see UNCTAD, 2000 and 2001).

- the scope for expanding the production of various kinds of land, forest and aquatic biomass for diversified uses, such as food, animal feed, energy, fertilizers, construction materials, industrial feedstocks and pharmaceuticals. Several developing countries have a bright future in this respect, provided that they explore their biodiversity skillfully by means of biotechnologies, both with a view to enhancing the output of biomass and enlarging the spectrum of products derived from it. In this way, they can embark, ahead of industrial countries, upon a genuinely sustainable and fairly labour-intensive development pattern, provided that they respect the rules for the ecologically sound management of forests, land and water (see Sachs, 2000b, 2001a and 2001b);

- the activation, through labour-intensive methods, of non-investment sources of growth in two ways:

- by paying greater attention to the productivity of natural resources through energy and water conservation, the recycling of waste and productive uses of agricultural residues (Sachs, 1988; Weizsacker et al., 1998); and

- by ensuring better maintenance of the existing stock of infrastructure, equipment and buildings, so as to expand their life cycle and, in this way, liberate for additional productive investment the capital that would otherwise be required for their renewal; ${ }^{18}$ and

${ }^{18}$ In his theory of growth, Kalecki introduced two parameters responsible for non-investment growth: the rate of real depreciation and the coefficient of better utilization of the existing productive capacities. The lower the depreciation rate (achieved through better maintenance), the higher, ceteris paribus, the rate of economic growth. A better utilization of existing productive capacity will also lead to a higher rate of overall growth. 
- $\quad$ last, but certainly not least, how to address the future of the toiling majority of petty producers, the self-employed and those working in family farms and businesses that are not organized as enterprises, and to follow a rationality pattern similar to that observed by Chayanov in peasant agriculture.19 This question is addressed in the next section.

For many developing countries, a 2 per cent annual growth of employment is the minimum required to absorb newcomers on the labour market. The reduction of unemployment and underemployment requires the combinations of $r$ and $p$ situated on the right of diagonal 2 in the table in Box 1. All the combinations on the left of this diagonal represent a worsening of the employment situation.

Rox 1 Rates of growth of employment
The rate of growth of employment $e$ depends on the rates of growth of GNP r and of labour productivity
$p: e=r-p$

${ }^{19}$ Money flows easily from the enterprise pocket to the domestic pocket, and vice versa, which is totally contrary to the rationality observed in organized enterprises. 


\section{From petty producers to micro-entrepreneurs}

The category "petty producers" includes all those engaged in small-scale activities conducted outside the universe of modern enterprises. The latter consists of large and medium firms, and of a variety of small-scale industrial, commercial and service enterprises, some of them uni-personal, ranging from shops and restaurants to sophisticated high-tech start-ups and consultancy firms. Micro- and small businesses account for the majority of jobs in the modern economy. But this does not mean that their capital/labour coefficient is necessarily low. ${ }^{20}$

The challenge ahead is the transformation of petty activities into organized small-scale enterprises capable of competing in the mainstream capitalistic market. Their graduation will be a result of upgrading their skills and managerial capacities (increasing intra-firm competitiveness) and improving their systemic competitiveness though a set of converging affirmative actions, such as preferential access to credit, technology and markets.

Designing such actions presupposes a detailed knowledge of the working of the real economy ("substantive" in the terms of Polanyi) going beyond the formal-informal dichotomy. The complexity of the real economy is seldom acknowledged in mainstream economics. It stems from the simultaneous presence of several modes of production:

- $\quad$ non-market (production of goods and services for self-consumption);

- petty pre- and proto-capitalistic production (PPPP) by artisans, street vendors, providers of personal services and in domestic businesses, shops, stalls and cottage industries; ${ }^{21}$

- the capitalistic profit-oriented market economy, including large and small, national and foreign-owned, private and public enterprises; and

- the social economy, which is market but not-for-profit oriented, including cooperatives, self-managed enterprises, organizations of civil society and charities. ${ }^{22}$

Family agriculture partakes in all four of the above modes of production. Public services provided free-of-charge form a category apart.

${ }^{20}$ The capital/labour coefficient $i$, the capital output ratio $k$, and labour productivity $p$ are linked by the following identity: $i=k x p$. Furthermore, many small modern enterprises are knowledge-intensive.

21 The distinction between cottage and modern small-scale industries has been long established in India (Dhar, 1958; Sen, 1960). Most domestic businesses are not run as enterprises and a close parallel can be established between them and family peasant farms.

${ }^{22}$ See Jeantet (1999). In Brazil, the social economy is known as the solidary econmy (Singer and Souza, 2000). 
All goods and services enter the following circuits:

- the domestic economy; ${ }^{23}$

- the "popular economy", supplying the low-income population with cheap goods and services mainly, but not exclusively, produced by local petty producers, who must face competition from cheap goods smuggled from abroad or specially designed for low income consumers by multinational firms; these goods circulate in the popular economy through door-to-door distribution schemes; ${ }^{24}$

- the mainstream capitalist market, to which petty producers accede as providers of personal services, tertiarized services to firms, as street and door-to-door vendors and, occasionally, as subcontractors of organized industries; and

- $\quad$ public purchases, a potentially important instrument for affirmative action in favour of petty and small-scale producers ${ }^{25}$

The segmentation of markets for goods and services goes side-by-side with the segmentation of the labour market. Public servants and employees of organized private firms enjoy a privileged status compared with petty producers, as they are protected by labour laws, have access to social services and are entitled to retirement benefits. Nevertheless, many petty producers seem attached to their informality, arguing that they are better off in terms of immediate gains by evading taxation and social charges. This is a short-sighted and ultimately fallacious view, but it clearly shows the kind of policies that are necessary to stimulate the access of petty producers to the organized economy, whether capitalist or social; the two options are available, the former dominant, the latter socially preferable.

As mentioned above, petty producers must be given an opportunity to upgrade their activities by improving their skills through training. This is critically important for the growing numbers of providers of technical and maintenance services to urban and rural households and firms. The demand for technical, but also social and personal services, is likely to increase in rural areas, accompanying the modernization of agriculture and the establishment of biomass processing industries. Services can offer an important employment outlet for members of traditional farming families as part of rural development strategies that encourage pluriactivity.

Organizational upgrading is as important as technical upgrading. Petty producers who are in the process of becoming small entrepreneurs have to improve their management culture.

23 Barter is, on the one hand, an extension of the domestic economy and, on the other, a means of exchanging goods and services produced for the market without using money because of abnormal conditions in the monetary economy (such as hyperinflation of a shortage of currency).

24 In Brazil, an American-based giant cosmetics industry, Avon, has a network of over 700,000 door-to-door sales personnel.

25 The United States has elaborate legislation according small-scale businesses preferential treatment in public purchases. 
At the same time, they should be assisted to take advantage of mutual aid and collective entrepreneurship as powerful means of strengthening their individual endeavours. ${ }^{26}$

Collective entrepreneurship can take different forms, ranging from group guarantees in micro-credit schemes, to fully-fledged savings and credit, production and trading cooperatives,${ }^{27}$ saving and credit rotation associations, and including sectoral and territorial groupings of producers and traders seeking economies of scale and better prices through joint purchases or sales and positive externalities for their businesses through collaborative action in the fields of technology, design and marketing.

Competition does not exclude cooperation, as we have learnt from the experience of Marshallian industrial districts in North-Eastern Italy (La terza Italia in the terms of Arnaldo Bagnasco, 1988), also known as clusters, concentrating hundreds or even thousands of similar workshops and small industrial units in a township or micro-region. ${ }^{28}$ Clusters would appear to be a particularly important field for public policies aimed at gradually transforming petty producers into micro- and small entrepreneurs.

Important as it is, the promotion of collective entrepreneurship has to be supplemented by several converging and mutually reinforcing public policies.

Experience has shown that land reforms do not work unless land distribution is complemented by measures to break the power of moneylenders and traders entrenched in the countryside, so that traditional farmers can rely simultaneously on the following requisites for the successful modernization of family agriculture:

- $\quad$ access to appropriate technologies (both knowledge and labour-intensive, and capital and resource-saving), skills and efficient extension services;

- $\quad$ subsidized credits for production and investment;

- guaranteed minimum prices, fair access to markets and preferential treatment on institutional markets (public purchases); and

- $\quad$ assistance in identifying local, national and foreign market niches for quality products (such as cheeses, wines, fruit and vegetables).

${ }^{26}$ For the role of mutual aid in social evolution, see Kropotkin (1902).

${ }^{27}$ A caveat is in order here. In Brazil, employers sometimes replace regularly employed workers by contracting the services of workers' cooperatives, thereby avoiding the payment of social charges. Needless to say, this is a total distortion of cooperative ideals which should be vigourously opposed.

${ }^{28}$ Brazilian institutions, inspired by pioneering ILO studies (Pyke, Sengenberger and Becattini, 1990; Pyke and Sengenberger, 1992) and collaborating closely with Italian counterparts, are discovering hundreds of industrial clusters spread all over the country specialized in such areas as garments, shoes and leather goods, furniture and precious stones. An atlas of these clusters is being prepared by SEBRAE. The goods produced in the clusters are often commercialized by street and door-to-door vendors, known in Brazil as sacoleiras (literally women carrying bags), who visit the clusters in their thousands to buy products directly from the producers, often travelling long distances to do so. SEBRAE intends to give high priority to a programme for the consolidation and development of clusters. 
None of these prerequisites will be fulfilled in the absence of vigorous public policies designed and implemented by a lean, clean and development-minded State (see Box 2; Sachs, 2000a; and Rodrik, 2000).

The same is true for petty producers engaged in crafts, cottage industries, services and trade. To assist in their gradual transformation into micro-entrepreneurs and their integration into the mainstream organized economy, the following measures have been recommended by a recent Brazilian study sponsored by SEBRAE (the Brazilian agency for the development of micro- and small enterprises) and UNDP (Sachs, 2002):

- the simplification of bureaucratic procedures and the reduction of administrative fees for the registration of new businesses;

- a simplified fiscal regime with significant tax reductions at all levels (federal, state and municipal);

- lower charges and simplified procedures for access to health and social protection;

- $\quad$ preferential treatment of micro- and small enterprises on institutional markets and the strengthening of linkages between large enterprises and small businesses through fair practices of subcontracting, tertiarization and franchising designed to protect the interests of the weaker partners; ${ }^{29}$ and

- $\quad$ last but not least, the provision of credit on a preferential basis.

The latter point calls for clarification. While the need for subsidized credit for farmers is widely recognized, international lending agencies by contrast consider that credits for small non-agricultural activities should not be subsidized, arguing that even the high administrative costs of micro-credits should be fully covered by those seeking the credit. The Grameen Bank is advocated as a model.

Transferred to the Brazilian context, micro-credit is provided by NGOs at real monthly interest rates ranging from 2 to 4 per cent. This means that they can at best cater for the needs of traders, who require a small working capital that they rotate several times a week or, for example, assist dressmakers and tailors to buy a second-hand sewing machine. The scope for such endeavours is quite limited when compared with the potential demand for credit by petty producers. As for the argument that these rates are lower than those sought by moneylenders, the answer is that the poor seldom go to moneylenders to finance productive investments.

It would seem that the prejudice against subsidizing credits for non-agricultural petty producers is of an ideological nature and has much to do with an aversion to subsidies as a policy instrument. Subsidies can be used for good or bad purposes, and can be properly or improperly designed, but they remain an important tool in the panoply of policy instruments available for affirmative action in favour of petty producers. The adequate provision of credit in many countries is still the weakest element in the development policy package. There is a shortage of in-depth studies on the diversified patterns of demand for credit that take into consideration the affordability of the solutions proposed.

29 On the linkages between large multinational enterprises and their contractors, see UNCTAD (2000 and 2001). 


\section{Territorial development, empowerment and local initiatives}

The extreme diversity of socio-economic and cultural configurations, as well as resource endowments, prevailing in the various micro- and meso-regions means that uniform development strategies cannot be applied across the board. To be effective, these strategies have to respond to the most pressing problems and aspirations of each community and be successful in removing the bottlenecks that obstruct the utilization of latent and idle resources, so as to free up social energies and imagination. For this to happen, the participation in the development process of all the stakeholders (workers, employers, the State and organized civil society) must be secured.

Hence the importance of territorial planning at the level of townships, micro-regions and meso-regions regrouping several districts which are united by cultural identity and common interests. For this purpose, spaces for the exercise of direct democracy should be created in the form of local development forums evolving into consultative and then deliberative councils, so as to empower communities to assume an active and often creative role in shaping their own future. ${ }^{30}$

The largest fairly successful experiment in local participatory planning was undertaken in the Indian State of Kerala (Isaac and Franke, 2000). In the last four years, Brazil has also launched an ambitious programme targeting the thousand municipios $^{31}$ with the lowest HDI (Human Development Index) with a view at inducing them to define priorities for local integrated and sustainable development through public discussion. This effort has been organized jointly by Comunidade Solidária (a body coordinating the social programmes of the Brazilian State) and SEBRAE, and assisted by the Agency of Education for Development (AED), especially created for this purpose. The results are yet to be analysed.

Another initiative going in the same direction is the preparation of the first National Rural Sustainable Development Plan which will emphasize the enormous, yet unexplored potential for the further development of several Brazilian micro and meso-regions.

A third line of action already mentioned relates to the consolidation and development of industrial districts (clusters).

\footnotetext{
${ }^{30}$ For the concept of empowerment, which is central to development politics, see Friedmann (1999). For the emergence of organized civil society as the third system of power, see Nerfin (1986) and, more generally, the whole collection of IFDA dossiers (International Foundation for Development Alternatives). See also What Now? (1975).

${ }^{31}$ The municipio is the lowest administrative unit in Brazil. There are 5,561 municipios.
} 
Finally, reference should be made to a very positive experience in the highly industrialized area of the São Paulo metropolitan region, known as $\mathrm{ABCD} .{ }^{32}$ Several municipalities joined in the creation of a regional development council, which is credited with several successful initiatives.

The empowerment of communities and the opening of space for direct democracy constitute the key to development politics (Friedmann, 1992), prefiguring a new paradigm of mixed economies functioning through dialogue, negotiation and contractual links between development stakeholders. No doubt bottom-up initiatives will grow in importance. However, it is not possible to build a national development strategy by simply aggregating local development initiatives, if for no other reason than because these initiatives have to be harmonized in order to seek collaborative arrangements and synergies, rather than wasteful duplication. Planning is an iterative process including both bottom-up and top-down procedures, requiring the framework of a long-term national project, ${ }^{33}$ a vision shared by the majority of the nation's citizens concerning values, their translation into societal goals and the insertion of their nation State into a globalizing world. ${ }^{34}$

\footnotetext{
${ }^{32}$ From the name of the towns that integrate it: Santo André, São Bernardo, São Caetano, Diadema.

${ }^{33}$ According to Jean-Paul Sartre, man is a project. A fortiori, human societies should be seen as projects.

${ }^{34}$ UNCTAD is right to say that we live in an already liberalized and still globalizing world.
} 
Box 2

Whither the nation State?

In the absence of inclusive globalization, nation States will continue to be the main locus of inclusive development strategies. The progress achieved will depend on the ability to transcend the excessive emphasis on macroeconomic regulation, combined with an overestimation of the role of micro-economic rationality at the firm level by strengthening meso-level institutions and policies. Much will depend on the answers that are provided to the following questions:

- What State, what markets, for what development?

- What institutional and legal mechanisms to ensure transparency and real everyday democracy in the working and regulation of the mixed economy?

- What role for the State in promoting the social finality of development, while respecting the rules of environmental prudence and economic efficiency? How should social considerations fit into the design of development strategies? In particular, how to design fine-tuned employment policies as the cornerstone of proactive social policies?

- What role for the public sector in providing the necessary infrastructure for development and in ensuring systemic competitiveness?

- What forms of articulation between public, private profit and non-profit, cooperative and communal patterns of ownership?

- What forms of partnership and symbiotic cooperation between the social actors in development ?

- What modalities of articulation between the different levels of decision-making and implementation (what concrete meanings for the concept of subsidiarity)?

- What forms of selective insertion into the international economy to ensure the right mix of openness and protection? More broadly, what kind of relationship between internal governance and the emerging system of global governance?

See also Sachs (2001b) and Wade (1990).

\section{Inclusivity and globalization}

Throughout this paper, it has been assumed that sovereign nation States are and will continue to be the main locus for promoting inclusive development. In a recent article, Kofi Annan (2002) recalled that the Arabic translation of the word "globalization" means literally "world inclusivity". Yet, the asymmetric and inequitable forms of globalization prevailing today are detrimental to the interests of developing countries, while profiting some insiders and leaving behind many outsiders. The insiders live in a reformed capitalism, while the outsiders are condemned to harsher or even savage forms of capitalism. The nation States in developing countries strive to act as a shield protecting their people from the further deterioration of their predicament. In its present forms, globalization reproduces between central and peripheral nations the same perverse concentrating and excluding pattern of growth observed within nations. 
As a matter of symmetry, through inclusive development it is possible to postulate the coming into being of inclusive globalization through the institution of an international economic order based on the principle of the unequal treatment of unequals, ${ }^{35}$ the promotion of fair trade, ${ }^{36}$ the increased flow of public aid without strings attached and the transformation of science and technology into public goods (in sharp contrast with TRIPS).

Needless to say, inclusive globalization would greatly facilitate the transition towards inclusive development. But, in the foreseeable future, the chances of advancing in this direction are rather slim. This serves to underline the crucial importance of national strategies based on the concept of "development from within" (Sunkel, 1993), which should not be mistaken as a call for inward-looking strategies.

${ }^{35}$ In practice, this principle was first formulated with respect to international economic relations, among others by Gunnar Myrdal (1956), and constitutes the cornerstone on which UNCTAD was founded.

${ }^{36}$ See on this point Oxfam (2002) and the annual UNCTAD reports. 


\section{Bibliography}

Annan, K. 2002. "The walls have to come down", in International Herald Tribune. 4 October.

Bagnasco, A. 1988. La costruzione sociale del mercato. Bologna, Il Mulino.

Bielschowsky, R. (ed.). 2000. Cinquenta anos de pensamento na CEPAL. Rio de Janeiro, Record.

CEPAL. 2002. Globalización y desarrollo: Una reflexión desde América Latina y el Caribe. Santiago de Chile.

Dhar, P. N. 1958. Small scale industries in Delhi. Bombay, Asia Publishing House.

Drucker, P.F. 1986. “The changed world economy”, in Foreign Affairs. Spring: 768-791.

Ferrer, A. 1997. Hechos y ficciones de la globalización: Argentina y el Mercosur en el sistema internacional. Buenos Aires, Fundo de Cultura Económica.

----. 2002. Vivir con lo nuestro: Nosotros y la globalización. Buenos Aires, Fundo de Cultura Económica.

Friedmann, J. 1992. Empowerment: The politics of alternative development. Oxford, Blackwell.

Gorz, A. 1988. Métamorphoses du travail: Quête du sens. Paris, Galilée.

Ha-Joon Chang. 2002. "The Stiglitz contribution”, in Challenge. March: 93-94.

Illich, I. 1977. Le chômage créateur: Postface à la convivialité. Paris, Le Seuil.

ILO. 2001a. Reducing the decent work deficit: A global challenge. Report of the Director-General. Report 1(A). International Labour Conference, 89th Session. Geneva.

----. 2001b. Promotion of cooperatives. Report V(1). International Labour Conference, 89th Session. Geneva.

----. 2002a. Decent work and the informal economy. Report VI. International Labour Conference, 90th Session. Geneva.

----. 2002b. "Reply by the Director-General to the discussion of his Report", in Provisional Record, 17. International Labour Conference, 90th Session. Geneva.

----. 2002c. A future without child labour: Global Report under the Follow-up to the ILO Declaration on Fundamental Principles and Rights at Work. Report 1(B). International Labour Conference, $90^{\text {th }}$ Session. Geneva.

----. 2003. Review of the core elements of the Global Employment Agenda. Doc. GB.286/ESP/1(Rev.), March. Geneva.

Isaac, T.M.T. and Franke, R.W. 2000. Local democracy and development: People's campaign for decentralised planning in Kerala. New Delhi, Leftword.

Jeantet, T. 1999. L'économie sociale européenne. Paris, CIEM.

Kannan, K.P. and Pillai, N.V. 2002. Plight of the power sector in India: SEBs and their saga of inefficiency. Trivandrum, Centre for Development Studies.

Kothari. R. 1993. Growing amnesia: An essay on poverty and the human consciousness. New Delhi, Viking/Penguin Books. 
Kropotkin, P. 1902. Mutual aid: A factor of evolution. Montreal, Black Rose Books (1988 edition).

Kuttner, R. 1997. Everything for sale: The virtues and limits of markets. New York, Knopf.

Meier, R.L. 2000. "Late-blooming societies can be stimulated by information technology", in Futures. 32(2): 163-181.

Myrdal, G. 1956. An international economy: Problems and prospects. New York, Harper.

Nerfin, M. 1986. Neither prince nor merchant: Citizen - an introduction to the third system. Nyon, International Foundation for Development Alternatives. Dossier No. 56. November-December: 3-29. Reprinted in Development Dialogue. 1987, No. 1.

Oxfam. 2002. Rigged rules and double standards: Trade, globalization and the fight against poverty. Oxford.

Pochmann, M. (ed.). 2002. Desenvolvimento, trabalho e solidariedade: Novos caminhos para a inclusão social. São Paulo, Cortez Editora.

Pyke, F. and Sengenberger, W. 1992. Industrial districts and local economic regeneration. International Institute for Labour Studies. Geneva, ILO.

Pyke, F., Becattini, G. and Sengenberger, W. (eds.). 1990. Industrial districts and inter-firm cooperation in Italy. International Institute for Labour Studies. Geneva, ILO

Revista Latinoamericana de Estudios del Trabajo. 1999. Heterogeneidades no trabalho. 5(9).

Ricupero, R. 2002. Esperança e ação: A ONU e a busca de desenvolvimento mais justo. São Paulo, Paz e Terra.

Rodriguez, O. 1998. "Heterogeneidad estructural y empleo", in Revista de la CEPAL. Número extraordinario, CEPAL 50 Anos. October.

Rodrik, D. 2000. A valiosa herança da economia mixta: O Estado de São Paulo. 6 de agosto.

Rousseau, J.-J. 1755. Discours sur l'origine et les fondements de l'inégalité parmi les hommes. Paris, Livre de Poche (1996 edition).

Sachs, I. 1971. “A welfare state for poor countries”, in Economic and Political Weekly. 6(3-4): 367-370.

----. 1988. "Work, food and energy in urban eco-development", in Economic and Political Weekly. 13(9), 27 February: 425-444.

----. 1998. "The state and the social partners: Towards a development compact", in Economic and Political Weekly. 15-22 August: 2233-2239.

----. 1999. "L'économie politique du développement des économies mixtes selon Kalecki: Croissance tirée par l'emploi”, in Mondes en développement. 27(6), Paris-Bruxelles.

----. 2000a. Understanding development: People, markets and the State in mixed economies. New Dehli, Oxford University Press.

---- 2000b. "Brésil: Tristes tropiques ou terre de bonne espérance? Tropicalité, tropicologie et développement", in Hérodote. 98: 184-201.

----. 2001a. "Brasil rural: Da redescoberta à invenção", in Estudos Avançados. 15(43): 75-82.

----. 2001b. "Um projeto para o Brasil: a construção do mercado nacional como motor do desenvolvimento", in Bresser Pereira, L.C. and Rego, J.M. (eds.), A grande esperança em Celso Furtado: Ensaios em Homenagem aos seus 80 anos. São Paulo, Editora 34. 
----. 2002. Desenvolvimento humano, trabalho decente e o futuro dos empreendedores de pequeno porte no Brasil. Brasilia, SEBRAE-UNDP.

Sen, A. 1960. Choice of techniques: An aspect of the theory of planned economic development. Oxford, Blackwell,

----. 1987. On ethics and economics. Oxford, Blackwell.

----. 1999. Development as freedom. New York, Knopf.

Sengupta, A. 2001. "Development policy and the right to development", in Frontline. 18(4), February 17-March 2: 91-96.

Singer, P. and Souza, R.D. (eds.). 2000. A economia solidária no Brasil: A autogestão como resposta ao desemprego. São Paulo, Contexto.

Soros, G. 2002. On globalization. New York, Public Affairs.

Souza Martins, J. 2002. A sociedade vista do abismo. São Paulo, Vozes.

Stiglitz, J.E. 2002. Globalization and its discontents. New York, Norton.

Streeten, P. 2001. Globalization: Threat or opportunity? Copenhagen Business School Press.

Sunkel, O. (ed.). 1993. Development from within: Toward a neostructuralist approach for Latin America. Boulder, Rienner.

UNCTAD. 2000. TNC-SME linkages for development: Issues-experiences-best practices. New York and Geneva.

----. 2001. World investment report 2001: Promoting linkages: Overview. New York and Geneva.

UNDP. 2000. Overcoming human poverty: Poverty report 2000. New York.

----. 2002. Human development report 2002: Deepening democracy in a fragmented world. New York

Wade, R. 1990. Governing the market: Economic theory and the role of government in East Asian industrialization. Princeton University Press.

Weizsacker, E., Lovins, A.B. and Lovins, H. 1998. Factor four: Doubling wealth - Halving resource use. London, Earthscan.

What now? 1975. Dag Hammarskjöld report on development and international cooperation. Development Dialogue. 1/2. Uppsala.

Ziegler, J. 2002. Les nouveaux maîtres du monde et ceux qui leur résistent. Paris, Fayard. 


\section{Policy Integration Department Working Papers prepared for the World Commission on the Social Dimension of Globalization}

No. 16 International finance: Meeting the needs of people in developing countries, José Guilherme Almeida dos Reis

No. 17 The gender dimensions of the globalization of production, Stephanie Barrientos, Naila Kabeer and Naomi Hossain

No. 18 Social exclusion in the context of globalization, Jan Breman

No. 19 Gender and globalization: A macroeconomic perspective, Çağatay Nilüfer and Ertük Korkurt

No. 20 Globalization, social exclusion, and work: with special reference to informal employment and gender, Marilyn Carr and Martha Chen

No. 21 Resources for social development, Anthony Clunies Ross

No. 22 Does the new international trade regime leave room for industrialization policies in the middle-income countries?, Alisa DiCaprio and Alice Amsden

No. 23 Social dimension of globalization in Latin America: Lessons from Bolivia and Chile, Alvaro García Hurtado

No. 24 Globalization: Social impact and policy actions: A partly annotated bibliography, Bernhard Gunter and Rolph van der Hoeven

No. 25 The social dimension of global production systems, Susan Hayter

No. 26 Reforming global economic and social governance:

a critical review of recent programmatic thinking, Jeremy Heimans

No. 27 Corporate social responsibility: An issues paper, Michael Hopkins

No. 28 Upgrading in global value chains, John Humphrey

No. 29 Implications of globalization and economic restructuring for skills development in Sub-Sahara Africa, Richard K. Johanson

No. 30 The outcome and impact of the main international commissions on development issues, Frédéric Lapeyre

No. 31 Globalization and structural adjustment as a development tool, Frédéric Lapeyre

No. 32 Globalization and perceptions of social inequality, Malte Luebker

No. 33 The changing structure of trade linked to global production systems:

What are the policy implications?, William Milberg

No. 34 Corporate social responsibility: An overview of principles and practice, Jill Murray

No. 35 Inclusive development strategy in an era of globalization, Ignacy Sachs

No. 36 Social consequences of the globalization of the media and communications sector: Some strategic considerations, Seán Ó. Siochrú

No. 37 Globalization, history and international migration - A view from Latin America, Andrés Solimano

No. 38 Towards a different kind of globalization, or how the anti-globalizers view the world, Gijsbert van Liemt 
